\title{
Efeitos de sentido em "Dois perdidos numa noite suja", de Plinio Marcos, um discurso (em) cena
}

Sense effects in Two lost in a dirty night, by Plínio Marcos, a discourse

(in) scene

\section{Cezar Roberto Versa}

Alexandre Sebastião Ferrari Soares

Universidade Estadual do Oeste do Paraná, Cascavel, PR, Brasil

Resumo: O teatro de Plínio Marcos se demarca por formações discursivas e ideológicas singulares, em que seus personagens são sujeitos assujeitados e interpelados constantemente pela ideologia marginalizante do sistema capitalista. Os personagens materializam sentidos em seus discursos por meio das situações de condição existencial extremada. Neste trabalho, objetiva-se analisar os efeitos de sentido dos enunciados dos personagens de Dois perdidos em uma noite suja. A abordagem teórico-metodológica se perfaz nos conceitos da Análise do Discurso de linha francesa. A justificativa de tal proposta se efetiva nos poucos estudos acerca das obras do dramaturgo Plínio Marcos, em especial, focadas na discursividade presente em suas peças.

Palavras-chave: Teatro. Análise do Discurso. Efeitos de sentido.

Abstract: The Plínio Marcos' theater is demarcated by unique discursive and ideological formations where its characters are individual in process of subjection and constantly interpellated by marginalizing ideology of the capitalist system. The characters materialize senses in their speeches through situations of extreme existential condition. In this paper we aim to analyze the sense effects of characters' utterances in Two lost in a dirty night. The theoretical-methodological approach is supported on the concepts of French Discourse Analysis. The justification of such proposal is due to the few studies on the works of the playwright Plínio Marcos, especially focused on discursivity present in his plays.

Keywords: Theater. Discourse Analysis. Sense effects. 


\section{Introdução}

A produção de sentidos do discurso dos protagonistas da peça Dois perdidos numa noite suja, de Plínio Marcos, suscita uma oportunidade interessante e singular de revisão crítica de um universo demarcado pela marginalidade e pelo uso constante de gírias e palavrões. De tal monta, este Cezar artigo pretende analisar, por meio da Análise do Discurso de linha franRoberto Versa

Alexandre cesa (AD), as condições de produção e os efeitos de sentido dos enunciados das personagens da obra dramatúrgica do autor e jornalista paulista.

Sebastião

Ferrari Soares

Numa primeira parte da discussão, apresenta-se uma reflexão epistemológica, teórica e conceitual da $\mathrm{AD}$, entendida neste trabalho como fundamentação e metodologia de análise. Num segundo momento, delineiam-se algumas características do teatro de Plínio Marcos, para na sequência definir questões acerca do discurso das linguagens especiais, ratificadas no objeto de pesquisa. Tais abordagens sustentam a análise efetuada a posteriori.

A escolha pela $\mathrm{AD}$ enquanto abordagem teórico-metodológica de análise de uma peça teatral se deve à possibilidade de interpretação de sentidos baseados na discursividade da tessitura dramatúrgica, a qual se postula em condições de produções demarcadas nos enunciados de cada persona. Ademais, essa obra apresenta características singulares, como o discurso das linguagens especiais, e, ainda, poucos são os estudos que abrangem tais especificidades no nível discursivo.

\section{Análise do Discurso}

A Análise do Discurso é uma linha teórico-metodológica de interpretação que se orienta por perspectivas diferenciadas, uma vez que a palavra discurso dá margem a inúmeras significações e postulados epistemológicos. Duas linhas, por assim dizer, salientam-se nesse cenário: a anglosaxã, conhecida por americana, cujo fundo é sociológico; e a francesa, pautada no materialismo histórico. A diferença fulcral das duas perspectivas se estabelece em relação ao entendimento da intencionalidade do sujeito, pois, contrariamente à tendência americana, a escola francesa "não considera como determinante essa intenção do sujeito; considera que esses sujeitos são condicionados por uma determinada ideologia que predetermina o que poderão ou não dizer em determinadas conjunturas histórico-sociais" (MUSSALIM, 2001, p. 113).

Aclaradas aprioristicamente as possibilidades de abordagem, tal discussão acerca da teoria do discurso centrar-se-á na abordagem da linha 
francesa, representada no edifício teórico de Michel Pêcheux (1997). Para tanto, é necessário destacar que a AD francesa não surge do nada, num momento de genialidade autoral, como o próprio Pêcheux salienta.

A AD é uma teoria de ruptura, resultado de uma série de reflexões filosóficas e epistemológicas, construídas a partir de críticas ao realismo metafísico platônico e ao empirismo lógico aristotélico, cujas representações de sentido se efetivam na dualidade lógica e retórica, em que a primeira ressoa em relação à segunda. 0 materialismo é a alternativa viável para a saída dos idealismos tanto de Platão quanto de Aristóteles, atrelado ainda aos estudos da psicanálise. Faz-se importante destacar o vínculo da linguística com a $\mathrm{AD}$ como processo de legitimação científica, o qual se reforça nas bases epistemológicas e teóricas do materialismo althusseriano e da psicanálise lacaniana. Possenti $(2005$, p. 357) destaca

Efeitos de sentido em "Dois perdidos numa noite suja" que "A $\mathrm{AD}$ pode tratar cada um desses 'temas' - mas os trará rompendo com o que a linguística faz com cada um deles."

Em relação às teorias filosóficas idealistas, o ideário de que a consciência cria a existência se torna o ponto de contradição aos entendimentos da $\mathrm{AD}$, pois o sujeito tem em si a aura de criação, é ele que sabe, cria, domina os objetos. Por isso, o materialismo se aclara como solução, uma vez que o sujeito não domina os objetos, sua existência é que determina a consciência, tendo, assim, um sujeito formado na intermediação. Nesse sentido, a AD se aproxima do entendimento que os sofistas tinham em relação à composição e relação com o real por meio da linguagem, posição divergente da dos idealistas.

Em Platão, os discursos seriam verdadeiros e falsos; quando se estabelecem na relação estrutural com o real são verdadeiros, quando não, falsos. Os nomes identificariam as coisas nomeadas, e a linguagem seria como o tear, seria a descrição e a representação do real; numa compreensão realista do sentido, as palavras representariam a realidade essencial das coisas.

Já Aristóteles destoava da noção de essencial, indo além do real, embora nele também se pautasse. Acrescenta o ideário do intelecto humano como fator propiciador de abstração, as entidades extralinguísticas poderiam ser nominadas, já delineia a ideia de metáfora. A linguagem a priori advém e representa o que o ser humano tem em seu espírito, no seu interior, trabalhando uma tríade: linguagem-alma-real. Para não ser relativista, afirma que as afecções da alma seriam as mesmas para todos e reproduziriam as semelhanças da estrutura do real. Estuda Lógica 
e trabalha um conceito de linguagem como um sistema suficientemente objetivo para funcionar de modo confiável para a comunicação.

A antinomia filosófica a essas duas correntes se estabelece no entendimento filosófico do real de base sofista, a qual relativizava o pressuposto de verdades universalmente válidas; logo, não haveria Cezar como captar a realidade per si. Para os sofistas, a realidade não produRoberto Versa

Alexandre ziria o discurso, e sim os discursos seriam produtores de realidades. 0 problema é que essas verdades nunca seriam desveladas, pois a linguaSebastião Ferrari Soares gem revelaria a própria linguagem; assim sendo, não há como acessar o real. O grande feito é já terem pensado em construção de sentidos e postularem a noção de que as palavras e os discursos significam: "Experimentar a perspectiva sofística envolve renunciar a essa expectativa tão arraigada: na linha do que sugere Ferraz (1997), trata-se de estar preparado para pensar talvez que a linguagem 'não diz o que é', mas em alguma medida 'faz ser o que diz"' (MARTINS, 2005, p. 453).

Pode-se depreender, a partir de uma analogia entre o entendimento sofista e o dos analistas do discurso, que o sujeito não tem em seu discurso uma intencionalidade, pois a realidade não construiria o discurso, e sim o contrário. Percebe-se, nesse sentido, que as bases da $\mathrm{AD}$ não são inéditas e que, ao desconstruir os parâmetros idealista-platônico e lógico-aristotélico, Pêcheux (1997) incorre numa leitura próxima aos pressupostos sofísticos de discurso e realidade.

Então, poder-se-ia perguntar: a AD é sofista? A resposta é a de que o entendimento do real estabelece um limiar de interface muito singular, mas a $\mathrm{AD}$ se gesta a partir de outras bases aquém do sofismo, destacando a sua matriz linguística, materialista e psicanalítica.

De acordo com Gadet et al. (1993, p. 39), é possível

\footnotetext{
[...] circunscrever a concepção que MP tem da língua através de algumas breves monografias, baseadas em seis nomes e temas da conjuntura linguística tal como ela se apresentava na França no início dos anos sessenta:

- Saussure e o estruturalismo

- a recepção de Chomsky e da GGT

- Harris

- Jakobson

- Benveniste e a enunciação

- Culioli.
} 
Da teoria estruturalista de Saussure importa especialmente a passagem da noção de função para funcionalismo de língua e a de efeito metafórico, possivelmente também por influência de Jakobson. De Chomsky advém a ideia de criatividade não subjetiva da língua, que resultará nas formações discursivas (FDs), as quais ditam o que o sujeito deve dizer; as noções de estrutura de superfície e estrutura profunda, em que a última seria a ideologia e a primeira seria o discurso, são de suma importância à $\mathrm{AD}$. Já o método de análise provém de Harris, que trabalhava com sentenças parafrásticas. Quanto ao fornecimento de reflexão teórica e instrumentos de análise linguística, o empréstimo é de Jakobson, o propositor de ver a unidade da língua como um sistema de subcódigos que em AD seriam análogos às FDs. Ainda de Jakobson e depois de Benveniste a questão da enunciação e enunciado se transpa-

Efeitos de sentido em "Dois perdidos numa noite suja" rece, e a teoria subjetiva de enunciação de Benveniste é rechaçada. Por fim, Culioli com o recurso ao termo lexis e a análise das determinações do nome e do verbo, importantes para a noção de pré-construídos.

Da perspectiva materialista, Althusser (1998), que havia sido professor de Pêcheux, a partir de seus Aparelhos Ideológicos do Estado (AIE), influenciará os entendimentos acerca da ideologia e do sujeito, pois o indivíduo, ao ser interpelado pela ideologia, torna-se Sujeito (com S maiúsculo):

O projeto althusseriano, inserido em uma tradição marxista que buscava apreender o funcionamento da ideologia a partir de sua materialidade, ou seja, por meio das práticas e dos discursos dos AIE, via com bons olhos uma Linguística fundamentada sobre bases estruturalistas. Mas uma Linguística saussureana, uma Linguística da língua, não seria suficiente; só uma teoria do discurso, concebido como o lugar teórico para o qual convergem componentes linguísticos e socioideológicos, poderia acolher esse projeto. É nesse contexto que nasce o projeto da AD. (MUSSALIM, 2001, p. 104-105).

Dessa reflexão, advém um dos conceitos mais caros à AD: o de sujeito assujeitado. Para completar essa conjuntura nocional de sujeito, a teoria psicanalítica de Lacan (1996). Pêcheux (1997, p. 133) afirma: "Se acrescentarmos, de um lado, que esse sujeito, com S maiúsculo - sujeito absoluto e universal -, é precisamente o que J. Lacan designa como 
o Outro (Autre, com A maiúsculo) [...] 'o inconsciente é o discurso do Outro"'. É possível, assim, perceber uma relação entre o recalque inconsciente lacaniano e o assujeitamento ideológico althusseriano. Atrelado a essa relação, destaca-se ainda que Lacan entendia o inconsciente estruturado como uma linguagem.

Cezar De modo sucinto, apresentou-se um quadro epistemológi-

Roberto Versa

Alexandre

Sebastião

Ferrari Soares

286 co e teórico da $\mathrm{AD}$, que não se encerra simplesmente, até porque sua complexidade possibilitaria uma discussão ainda bastante longa. Faz-se mister destacar que todo esse processo não ocorre de forma estanque e que a $\mathrm{AD}$ pode ser dividida em três fases demarcadas: AD-1, baseada na ideia de uma maquinaria discursiva, em que o discurso poderia ser interpretado via programas computacionais; AD-2, já pautada na noção de FD, das determinações do que pode/deve ser dito; e AD-3, que se pauta no primado do interdiscurso.

A AD se preocupa em entender as condições de produção e os efeitos de sentido. Para tanto, trabalha com conceitos como o de formação ideológica (FI), FD, discurso transverso, pré-construído e interdiscurso; "A teoria de M. Pêcheux dedica-se a pensar os efeitos de sentido no discurso. Sua preocupação nunca foi a questão 'O que isso significa?', mas como se instituem efeitos de sentido no discurso, no encontro da língua, o efeito-sujeito e a história." (TEIXEIRA, 2005, p. 16).

As FIs caracterizam um elemento dentro dos aspectos da luta nos aparelhos ideológicos althusserianos, "suscetível de intervir como uma força em confronto com outras forças na conjuntura ideológica característica de uma formação social em dado momento" (PÊCHEUX; FUCHS, 1993, p. 163). Já as FDs determinam o que pode ou deve ser dito a partir de uma certa conjuntura, a qual deriva das condições de produção (PÊCHEUX; FUCHS, 1993).

De acordo com Pêcheux (1997), o discurso transverso se encontra no nível de relação de um argumento com outro, vem de fora, diz o que implica; proporciona a ligação dos elementos, efetiva-se na articulação. O pré-construído, diferentemente, pauta-se no nível da troca de elementos; numa noção de equivalência, é o elemento que preenche o lugar de argumento. o interdiscurso, por sua vez, é a importação de um termo de uma FD e sua tradução metafórica para uma outra FD: "Nessa perspectiva, o interdiscurso, longe de ser o efeito integrador da discursividade, torna-se desde então seu princípio de funcionamento [...]." (PÊCHEUX, 2011, p. 159). 
A ilusão de um eu centralizador do sentido, da forma-sujeito, estabelece-se no que Pêcheux (1997) chamou de esquecimento $\mathrm{n}^{\circ} 1$, o qual não é acessível ao sujeito, pois é de matiz inconsciente e ideológico, o lugar constitutivo da subjetividade. $O$ esquecimento $\mathrm{n}^{\mathrm{o}}$ 2 se perfaz na ilusão de transparência da língua, do sentido; efetivase nos processos enunciativos, nas escolhas de seleção linguística, na relação de paráfrase ou ocultamento de uma palavra em detrimento de outra.

Em suma, os indivíduos são interpelados em sujeitos por meio da ideologia e se constroem em relação a outros sujeitos, numa estruturação de inconscientes. Ademais o sujeito é clivado, isto é, há um consciente e um inconsciente e, por mais que os sujeitos se entendam como fonte do sentido, retornam aos seus assujeitamentos, pois, ao sair de

Efeitos de sentido em "Dois perdidos numa noite suja" uma FD, entra-se em outra; e o ser humano é um ser de linguagem, um ser de sentidos.

\section{Teatro de Plínio Marcos}

Plínio Marcos de Barros nasceu em Santos, em 29 de setembro de 1935, e faleceu em São Paulo, em 19 de novembro de 1999. Com 16 anos, começou a atuar como palhaço. Tudo se iniciou porque Plínio Marcos queria namorar uma moça do circo e, como o pai da menina só a deixava namorar pessoas do meio circense, resolveu entrar para esse meio. 0 trabalho passou a ser um ofício a partir de seus 19 anos, quando saiu do quartel. Trabalhou na Companhia Santista de Teatro de Variedades, no Circo dos Ciganos, no Circo do Pingolô e da Ricardina, no Circo Toledo, entre outros.

Em 1958, escreveu sua primeira peça baseada num caso ocorrido em Santos, sobre um rapaz que havia sido preso e currado na cadeia e, dois dias depois de sair da prisão, matou quatro dos homens que o violentaram. Até então, o autor nunca havia pensado em escrever uma peça, e, ao lê-la aos seus amigos do circo, eles acharam-no louco. A peça chamou-se Barrela, que é a borra do sabão de cinzas, usado na época como gíria para curra.

Em 1960, Plínio Marcos decidiu ir para São Paulo, onde trabalhou, inicialmente, como vendedor de contrabandos, desde cigarros a rádios de pilha. Participou de testes para entrar em grupos teatrais da época, conseguindo participar de peças na Companhia de Cacilda Becker e do próprio Teatro de Arena. Em 1965, teve sua primeira peça encenada em 
São Paulo, Reportagem de um tempo mau, porém a censura a proibiu. Isso o frustrou muito, pois o teatro tinha se tornado sua profissão.

Após esse momento de decepção, o autor escreveu Dois perdidos numa noite suja. A inspiração e influência para a escritura da peça, confirma o próprio Plínio Marcos, vêm de um conto de Alberto Moravia, Cezar intitulado "O terror de Roma", pertencente a uma coletânea de contos Roberto Versa

Alexandre chamada de Contos romanos (2002). No conto do autor italiano, os sapatos representam também uma obsessão metafísica: "O narrador moSebastião Ferrari Soares raviano, que alugava uma cama de campanha, junto com Lorusso, no porão de um edifício, habitado também pelo porteiro e seus dois filhos, vivia com extrema dificuldade e suspirava por um par de sapatos novos" (MAGALDI, 1998, p. 217).

Dois perdidos numa noite suja passou pela Censura Federal, uma vez que era um momento de transição dos censores, ficando responsável pela decisão Coelho Neto, que, por ser do teatro, teve um discernimento acerca da liberação da obra. Alguns elogios de estudiosos do teatro paulista fizeram com que a peça se tornasse um sucesso; até Alberto D’Averssa, diretor teatral e crítico de destaque na década de 60 no Brasil, escreveu artigos sobre a peça. A partir daquele momento, o nome de Plínio Marcos voltou com força e representatividade, sendo que obras seguintes tornaram-se sucessos, como Navalha na carne (1967), Quando as máquinas param (1967), Homens de papel (1968), entre outras.

O teatro brasileiro das décadas de 60 e 70 do século XX marcou o momento de uma crítica significativa, em que Plínio Marcos interpreta uma série de problemas estruturais da ambiência sociopolítica brasileira por meio da linguagem e da criação de seus personagens. Contudo, seu nome no contexto dos estudos acerca de dramaturgos brasileiros, embora lembrado às vezes, ou brevemente citado, é muito precário. A relevância de sua obra teatral esteve relegada muitas vezes a juízos de valor, em que o estranhamento causado por suas peças, devido ao uso reiterado de palavrões, gerava um desconforto e até mesmo depreciação de sua produção artística.

Destarte, a linguagem utilizada nas peças é a característica mais marcante na produção de Plínio Marcos. Seu texto causa certa indisposição por apresentar tal característica de forma latente. Porém, ao se analisar com mais cuidado o estilo da linguagem carregada nas peças, observa-se que ela ultrapassa o recurso meramente estilístico. Isto é, o autor escrevia de acordo com o que as pessoas dos centros urbanos bra- 
sileiros marginalizados falavam. Seu ideal não era chamar a atenção dos poderosos para um Brasil muitas vezes esquecido, embora suas produções, no geral, fossem censuradas por destoar do que "devia ser dito".

o problema concernia na questão de que as peças desse dramaturgo representavam a cultura marginal e se constituíam justamente a partir dela, em oposição à cultura vigente e sem se melindrar quanto às regras institucionalizadas pelo sistema governamental da época. Assim sendo, retratar personagens comuns com seus problemas desvelava os processos de mascaramento social e isso não era interessante ao governo militar, pois essas máscaras respaldavam certas atitudes tomadas pelos que detinham o poder, seja em qual esfera melhor coubesse tal cerceamento enunciativo.

Para representar essas questões, Plínio Marcos construiu peças Efeitos de sentido em "Dois perdidos numa noite suja" de grande intensidade dramática, nas quais se evidencia uma realidade selvagem e violenta de uma sociedade marginalizada, esquecida e existente no bojo de um Brasil ditatorial.

O texto do dramaturgo paulista traz em sua tessitura marcas históricas e ideológicas que não podem ser negadas; mesmo que entendesse o seu teatro como algo que não visava protestar, as mazelas sociais se desvelavam em sua linguagem dramática. Mesmo tendo o tom coloquial como marca de seu texto dramático, esse fato não impediu seu teatro de atingir qualidade artística e refratar a sociedade do momento em questão, décadas de 60 e 70 do século XX:

\footnotetext{
Seu mundo é um mundo sujo, não resgatado pela menor luz de humanidade, no qual se debatem personagens sórdidas que lutam exclusivamente por dinheiro em meio às mais torpes corrupções, mundo que não oferece nenhum vislumbre de redenção. A linguagem é de uma crueza muito violenta. (CACCIAGLIA, 1986, p. 133).
}

Essa linguagem crua desvela um discurso da formação discursiva do ambiente de excluídos, raramente representados, salvo em casos em que suas imagens eram utilizadas para o protesto. Entretanto, uma evidenciação real da situação de pessoas marginalizadas não ocorria no teatro brasileiro.

Percebe-se que a violência exposta nos palcos começa a ser questionada e ao mesmo tempo imitada, tornando-se algo comum e até 
mesmo vazio em muitos casos. É justamente nesse aspecto que Plínio Marcos diferencia-se, pois sua produção não visa escrachar, meramente, a violência; mas sim interpretá-la como ambientação e situacionalidade de uma série de personagens que vivem uma cultura marginal e que demarcam na discursividade um discurso transverso da desumani-

Cezar zação como fonte de representação social.

Roberto Versa

\section{Discurso das linguagens especiais}

Alexandre

Sebastião

Ferrari Soares

O uso de gírias e palavrões tende a ser entendido como um discurso marginal, cujas formações discursivas se estabelecem em condições de produção relegadas a um plano de esquecimento pela sociedade entendida como "exemplar". Existiria um discurso da linguagem padrão e bem visto pelos componentes da sociedade tida como modelo, fato este que resultará em uma contraposição, pois ter-se-á também uma linguagem se formando à margem dessa sociedade, identificando grupos sociais minoritários ou de interesses específicos. Isto é, a língua se adapta e se modifica a partir das relações entre a própria língua, cultura e sociedade, produzindo discursos atrelados a interpelações ideológicas.

De acordo com Remenche (2003), essas linguagens aceitas como provindas de grupos minoritários e marginalizados, embora ressoem em práticas discursivas dos mais variados estratos sociais, serão reconhecidas e classificadas como linguagens especiais.

Essas linguagens especiais só começaram a ser desveladas em um nível macroestrutural a partir do final da década de 60 , quando começou a haver a expansão dos meios de comunicação de massa, como a televisão, o rádio e os textos publicitários, que pouco a pouco começaram a difundir as gírias e os jargões. $O$ uso desse tipo de linguagem proporcionou um maior grau de atenção dos espectadores, que de certo modo identificaram-se com tais termos, pois à margem dos atos de comunicação tradicional as pessoas os utilizavam há algum tempo.

De acordo com Remenche (2003), a palavra "gíria”, por exemplo, provém, etimologicamente, dos termos jerga e jeringonza, que apareceram em 1734, significando língua especial. Contudo, vários países tinham termos próprios para designar a língua especial, falada geralmente por classes restritas, pessoas marginalizadas, profissionais específicos etc.

$\mathrm{Na}$ Espanha, germanía era a gíria do submundo; para os portugueses, significava gíria antiga; na língua inglesa, havia o cant, ou 
canting, que mais tarde foi substituído pelo argot e usado pelos franceses e estadunidenses. Havia ainda o slang, considerada uma linguagem vulgar e erótica, delineada por muito tempo na Inglaterra como sinônimo de cant:

Germânia, cant, slang, argot e gíria percorreram caminhos diferentes, mas sua história tem a mesma natureza, pois vieram à tona através de grupos marginais, são caracterizados pelo rompimento com cânones linguísticos da sociedade dominante pelas mais diversas razões. (REMENCHE, 2003, p. 22).

Dessa forma, a gíria surge por meio de grupos marginalizados, ou ainda, minoritários ou de classes subalternas, advindo desse ponto seu caráter muitas vezes hermético. Em cotejo com o jargão, diferenciase pois está relacionada a grupos sociais, enquanto o jargão, a grupos profissionais. $O$ termo jargão remete, portanto, às expressões de classes profissionais específicas, como os jargões utilizados por médicos, engenheiros, professores, entre outros.

O calão, por sua vez, aproxima-se muito da gíria, contudo, na sua aplicação, denota-se um grau maior de intencionalidade, ironia e revolta com a sociedade. A etimologia da palavra "calão" advém de caló, nome dado à língua dos ciganos da Espanha e Portugal. Muitos confundiam o caló com a germanía, a gíria do submundo.

Em Portugal, o caló acabou por ser entendido como a língua dos malfeitores; no Brasil, tal classificação difere-se da encontrada na Lusitânia, uma vez que o caló era entendido como a linguagem carregada de termos obscenos e grosseiros devido ao contato entre os malfeitores e os ciganos. Logo, o aspecto mais pontual, exacerbado e intencional da gíria resulta no que se entende hoje por palavrão ou linguagem obscena.

o palavrão adquire, desse modo, o patamar de gíria proibida, pois empregar gíria incide em algo marginal, mais do que isso é empregá-la no seu sentido lato sensu. Logo, considerar o baixo calão apenas como uma linguagem marginal pode incidir em um preconceito linguístico, já que o valor semântico dos termos dependerá do lugar e momento em que são falados. Basta pensar seu aspecto no nível privado, em que nem sempre seu emprego remete à ofensa.

No entanto, cabe destacar que o palavrão ainda é encarado como uma linguagem pejorativa e de uso exclusivo das classes subalternas, o
Efeitos de sentido em "Dois perdidos numa noite suja" 
que é uma inverdade, pois o calão circula em todos os meios sociais. Porém, há todo um processo de manutenção do status quo, em que os sujeitos das classes sociais privilegiadas veem o palavrão como algo de mau gosto, embora o empreguem nas situações de maior grau de intimidade.

Percebe-se que o palavrão enceta em si uma propriedade con-

Cezar

Roberto Versa

Alexandre

Sebastião

Ferrari Soares tracultural quando proferido em níveis da esfera pública, pois choca-se com a moral e os "bons costumes" da sociedade tida como padrão; o discurso estabilizado é rompido.

\section{Efeitos de sentido (em) cena}

Em Dois perdidos numa noite suja, as personagens Tonho e Paco são dois jovens marginalizados e sem nenhuma expectativa de crescimento profissional, os quais se apresentam por meio de um diálogo tenso, dirigindo-se um ao outro por meio de termos pejorativos, numa linguagem de baixo calão. Tal fato indicaria a formação discursiva que perpassa o discurso dos dois rapazes, pobres e destituídos de expectativa de ascensão financeira, em que um objeto como um sapato simboliza a possibilidade de fuga desse universo simbólico de miserabilidade. A análise em questão se centra em alguns enunciados que produzem sentidos no universo dos interdiscursos de formações ideológicas e discursivas de um objeto como símbolo da saída da pobreza, dentro da lógica do discurso capitalista.

A peça é dividida em dois atos, o primeiro, mais extenso, é composto por cinco quadros, enquanto o segundo ato é apresentado em um bloco apenas. O cenário dos dois atos é o mesmo, um quarto de hospedaria muito simples com duas camas velhas e caixas de madeira improvisando o que seriam guarda-roupas e cadeiras. As paredes trazem figuras de mulheres nuas, pôsteres de times de futebol e recortes aleatórios.

Tonho e Paco são os sujeitos da trama, trabalham em um mercado e suas ânsias de vida pertencem a um contexto de materialização de angústias, demarcadas nos discursos ásperos e destoantes. Tudo se trava num embate de ofensas, o discurso que deveria ser humanizador toca as raias da animalização, uma simples gaita sendo tocada é motivo para afrontas.

TONHO - Ei! Para de tocar essa droga. (Paco finge que não ouve.)

TONHO - (Gritando) Não escutou o que eu disse? Para com essa zoeira! 
(Paco continua a tocar.)

TONHO - É surdo, desgraçado? (MARCOS, 2003, p. 66) ${ }^{1}$.

Os enunciados se materializam no nível discursivo da injúria; a forma-sujeito, de que cada um entende ser o centro do sentido, efetivase no entendimento que Paco tem em relação ao fingir não ouvir, no tom de ordem proferido por Tonho. Enfim, há dois sujeitos assujeitados duelando via linguagem, numa formação discursiva em que o palavrão parece ser a melhor arma, demarcando o apagamento de suas condições de existência.

Há no texto dramático uma série de caracteres que denotam a marginalização das personagens, as quais desejam se sobrepor à lógica do sistema, contudo não encontram possibilidades reais para que isso

Efeitos de sentido em "Dois perdidos numa noite suja" ocorra algum dia. Na condição de repulsa ao modo pelo qual vivem, em um ambiente sombrio que denota a exclusão social por eles vivida, veem-se como inimigos em um duelo.

$O$ assujeitamento dos sujeitos protagonistas da estória se demarca num discurso transverso de que "todo homem que é homem é macho", emergindo em vários dos enunciados o ataque a essa masculinidade, a qual é pertencente à formação discursiva e ideológica de um mundo patriarcal e capitalista, em que várias buscas, como o sucesso e a representação social, postulam-se nesse ideário do "homem de sucesso".

PACO - Boa, Tonho. Assim é que é. Homem macho não tem medo de homem. O negrão é grande, mas não é dois. (Pausa.) Você vai encarar ele? TONHO - Sei lá! Ele não me fez nada. Nem eu pra ele.

PACO - Poxa, ele disse que você é fresco. Vai lá e briga. Ele é que quer.

TONHO - Você só pensa em briga.

PACO - Eu, não. Mas se um cara começa a dizer para todo mundo que eu sou fresco e os cambaus, eu ferro o miserável. Comigo é assim. Pode ser quem for; folgou, dou pau. (Pausa.) Como é? Você vai fazer como eu, ou vai dar pra trás?

TONHO - Você podia quebrar meu galho com o negrão.

PACO - Eu, não. Em briga dos outros, eu não me meto. (p. 78).

PACO - Então quem se dana é você.

1 As citações referem-se a MARCOS, Plínio. Barrela, Dois perdidos numa noite suja, Navalha na carne, Abajur Lilás, Quero, uma reportagem maldita. São Paulo: Global, 2003, e, doravante, serão identificadas apenas pelo número da página. 
TONHO - Problema meu. Agora, que você nunca teve mulher, eu sei bem.

PACO - Juro que tive.

TONHO - Teve coisa nenhuma.

PACO - Filho da puta! (p. 93).

Cezar

Roberto Versa

Alexandre

Sebastião

Ferrari Soares

Tudo vai sendo dito entre Paco e Tonho, e os sentidos vão se materializando de modo injurioso, fato que só assevera a tensão e o conflito entre os personagens, mediante enunciados cada vez mais rudes. Um dos pontos altos da trama é quando Paco mostra seu sapato novo e nega o empréstimo ao colega de quarto Tonho, que tem no sapato a solução para a sua vida, pois uma boa aparência era a saída do mundo em que vivia.

TONHO - Você é uma besta.

PACO - Você tem um sapato velho, todo jogado-fora, e inveja o meu, bacana paca.

TONHO - Eu, não.

PACO - Invejoso!

TONHO - Cala essa boca! (p. 71).

Em consonância com o plano da linguagem empregada no texto está a linguagem do cenário. 0 modo pelo qual o ambiente é descrito nas rubricas indicia como a situação vivida pelas personagens é traumática, uma vez que o espaço social é degradado. A construção física do cenário representa o espaço social marginalizado em que se debatem por meio das palavras duas criaturas frágeis que trazem à tona conflitos humanos muito reais.

Paco e Tonho, por trabalharem no mercado, fazendo biscate, não conseguem vislumbrar um futuro melhor, uma vez que os discursos produzidos nessa formação discursiva são pautados na impossibilidade de oportunidades de crescimento e ascensão social, pois moram em uma hospedaria simples, fato que reflete sujeitos sem condições ideais de trabalho e recursos financeiros para vencer as condições adversas. Nesse sentido, o sapato constitui um interdiscurso com a falta de oportunidades, que aponta para o infortúnio social dos dois jovens dentro da lógica do discurso capitalista, em que sucesso, aparência, dinheiro e mulheres condizem ao homem de sucesso. 
TONHO - Você é que pensa. Eu fiz até o ginásio. Sei escrever à máquina e tudo. Se eu tivesse boa roupa, você ia ver. Nem precisava tanto, bastava eu ter um sapato... assim como o seu. Sabe, às vezes eu penso que, se o seu sapato fosse meu, eu já teria me livrado dessa vida. E é verdade. Eu só dependo do sapato. (p. 74).

Toda a expectativa de Tonho por uma melhoria de vida está representada num par de sapatos, sua ascensão social seria efetivada devido à sua aparência, mesmo que só tivesse os sapatos já pareceria uma pessoa mais importante. É como se os sapatos o transformassem em um outro homem, mais forte e poderoso.

A origem de Tonho é a de uma FD do homem do interior, simples e arraigado em certos valores morais, inclusive quanto à sua masculi-

Efeitos de sentido em "Dois perdidos numa noite suja" nidade, que sempre é questionada pelo colega Paco. Transpor o mundo rural ao urbano é deslocar sentidos, os quais se materializam na discursividade de seus enunciados.

TONHO - Não é medo. É que posso evitar a encrenca. Falo com o negrão e acerto os ponteiros. Poxa, se eu faço uma besteira qualquer, minha mãe é que sofre. Ela já chorou paca no dia que saí de casa.

PACO - Vai me enganar que você tem casa?

TONHO - Claro, como todo mundo.

PACO - Então, que veio fazer aqui? Só encher o saco dos outros? Poxa, fica lá na sua casa.

TONHO - Eu bem que queria ficar. Mas minha cidade não tem emprego. Quem quer ser alguma coisa da vida tem que sair de lá. Foi o que eu fiz. Quando acabei o exército, vim pra cá. Papai não pode me ajudar...

PACO - Quem tem papai é bicha.

TONHO - Você não tem pai, por acaso?

PACO - Claro que eu tive um pai. Não sou filho de chocadeira. Só que não sei quem é. Pai pode ser qualquer um. Mãe é que a gente sabe quem é. (p. 80-81).

Ratifica-se nesses enunciados o significado de família para Tonho, enquanto para Paco o valor de família se representa em uma única pessoa: a mãe, por meio de uma imagem idealizada. A questão do discurso patriarcal, de cunho machista, volta à tona quando Tonho chama seu pai de "papai" e Paco retruca dizendo que isso é coisa de bicha. 
Nesse ponto, pode-se observar que, devido a Paco não saber quem é seu pai, há uma tentativa de rebaixar o outro.

Na continuidade do diálogo entre Paco e Tonho, observa-se mais uma vez a preocupação da personagem vinda do interior com relação ao que pensa sua família. Tonho deve voltar para casa, mas antes deve Cezar conseguir ascender socialmente para ajudar a família.

Roberto Versa

Alexandre

Sebastião

Ferrari Soares

PACO - Vou te dar um alô. Volta pra tua casa. Aqui você só vai entrar bem.

TONHO - Vontade de voltar não me falta.

PACO - Então, vai logo, que já vai tarde.

TONHO - Não. Meu negócio é aqui.

PACO - Poxa, não escutou eu te dizer que aqui não vai dar pé?

TONHO - Não sei por que não vou me dar bem. (p. 81).

O diálogo entre as personagens evidencia a relação de poder explicitada quando Tonho pede os sapatos de Paco emprestados:

TONHO - Você podia me ajudar.

PACO - Ninguém me ajuda. Por que vou te ajudar?

TONHO - É só você me emprestar o sapato. Eu arranjo emprego, depois, se eu puder fazer uma coisa por você, eu faço.

PACO - Eu, te emprestar meu sapato? Não tenho filho do seu tamanho. TONHO - É só um dia.

PACO - Sai pra lá. Se vira de outro jeito. (p. 82).

A negativa do empréstimo é um modo de Paco demonstrar poder, ele detém os sapatos e, se isso pode mudar a vida de Tonho, só ocorrerá se ele (Paco) assim o quiser. Há uma questão significativa nesse trecho do ato: quando Paco diz que "Ninguém me ajuda. Por que vou te ajudar?", observa-se a presença do discurso individualista, que, dentro da formação ideológica das personagens, retrata o infortúnio de suas vidas e o cerceamento da possibilidade da ascensão social.

Tonho deseja saber onde Paco conseguiu os sapatos e, depois de pressioná-lo, descobre que foi por tocar muito bem flauta; embora o colega toque mal gaita, é um excelente flautista e sonha em ter uma flauta, porém não tem dinheiro para isso. 
O interdiscurso do sapato como objeto de ascensão e poder é o mesmo na flauta, uma vez que projetam nesses objetos a real possibilidade de superarem a vida que levam, saírem do lugar em que trabalham, ganharem mais do que ganham e deixarem para trás as pessoas com quem vivem. Mais uma vez, Paco é machista e demarca o discurso transverso do "homem macho" com o interdiscurso do homem de sucesso, pois sentava com "bacanas" e "metia o olho na coxa da mulherada":

PACO - Mas, quando aprender gaita, adeus, mercado. Dou pinote. Me largo da vida de novo. Não quero outra coisa. Só ali no come e dorme. Pelos bares enchendo a caveira de cachaça, às custas dos trouxas. Você precisa ver, seu. Arrumava cada jogada! Sentava na mesa dos bacanas. Bebia, bebia, bebia, tocava um pouquinho só e metia o olho na coxa da Efeitos de sentido em "Dois perdidos numa noite suja" mulherada. Era de lascar. Poxa, vida legal eu levava. (p. 91-92).

Tonho, no decorrer do diálogo, reitera que, se tivesse um sapato, tudo seria diferente. Fica evidente, na continuação do diálogo, que eles projetam nos objetos a solução para seus problemas:

PACO - Se eu tivesse a minha flauta, me mandava agora mesmo. Não ia te aturar nem mais um pouco. Você é chato paca.

TONHO - Você pensa que eu te adoro? Se tivesse sapato, já tinha me mandado.

(Paco começa a tocar.)

TONHO - Poxa, você precisa mesmo da flauta. Na gaita, você é uma desgraça.

PACO - Sem sapatos, você não vai longe. Não vai fugir do negrão. Só vai entrar bem.

TONHO - (Gritando.) Eu preciso de um sapato. Eu preciso de um sapato novo. (p. 94).

Os dois acabam cometendo um assalto, e Tonho consegue seu sapato; contudo, ao experimentá-lo, percebe que não serve, e mais uma vez o discurso transverso do "homem macho" se salienta:

PACO - A bichona tem pata grande

A patola da bicha é grande Grande, grande, grande 
A pata da bichona é grande

Ou o sapato é pequeno? (p. 126).

Aqui, as personagens de Plínio Marcos demonstram toda a sua pequenez diante de uma sociedade que os renega e os ignora, o assujei-

Cezar

Roberto Versa

Alexandre

Sebastião

Ferrari Soares

PACO - Assim. Bicha tem que obedecer. Não gosto de choradeira de bicha. Não gosta da sua droga de vida, se dane! Dá um tiro nos cornos e não enche mais o saco dos outros. Quer continuar respirando, continua, mas ninguém tem nada com a sua aporrinhação. Precisa de alguma droga? Desperta de arma na mão. Para que serve esse revólver que você tem aí? Usa essa porcaria? Ou se mata, ou aponta para a cara de um filho da puta, desses que andam por aí, e toma o que você quiser! Mas eu não quero escutar choradeira.

(Pausa.)

TONHO - Você tem razão. (Pega o revólver e fica olhando fixamente para a arma.) Você nunca mais vai escutar eu chorar. Nem você, nem ninguém. Pra mim, não tem escolha. 0 que tem que ser é. (Continua olhando a arma.) (Pausa.)

PACO - Esse revólver não tem bala.

TONHO - Eu sei. Mas é fácil botar uma bala no tambor. (Tira do bolso da calça uma bala e a olha fixamente, antes de colocá-la no tambor.) Como vê, Paco, agora não falta nada.

(Paco está sentado na cama, meio assustado. Pausa.)

PACO - Que vai fazer?

TONHO - Estou pensando.

PACO - Você vai se matar?

(Pausa.)

PACO - Você vai se matar?

(Pausa.)

PACO - Você vai acabar com você mesmo?

TONHO - (Bem pausado.) Vou acabar com você, Paco. 
PACO - Comigo? Poxa, comigo? Mas eu não te fiz nada. Você vai acabar com você mesmo?

TONHO - Você disse que eu era bicha.

PACO - Estava brincando.

TONHO - Pois é. Mas seu brinquedo me enchia o saco.

PACO - Poxa, se você não gosta, mixa a brincadeira e pronto.

TONHO - Você é muito chato, Paco. (p. 130-131).

Paco muda seu discurso e começa a negar tudo o que disse, afirmando que não vai mais chamá-lo de bicha, que pode trocar seus sapatos. Esse é o momento de maior tensão da peça, as personagens chegam ao ápice do desespero, e Tonho mata Paco, assumindo o discurso transverso do "homem macho" às raias do exagero, em seu sentido lato.

Efeitos de sentido em "Dois perdidos numa noite suja"

\section{Considerações finais}

Tonho e Paco, os protagonistas da peça, são dois indivíduos interpelados pela ideologia, assujeitados por completo, os sujeitos da formasujeito do discurso. Suas ânsias, angústias, além de sociais e históricas, estabelecem-se na clivagem consciente e inconsciente, perceptível na discursividade dos enunciados.

Os dois jovens simbolizam a confluência de processos sociais e históricos. 0 primeiro vindo do interior com uma tradição arraigada no discurso de um Brasil arcaico e patriarcal, e o segundo, produto de uma sociedade urbana cujas relações afetivas são escorregadias, mas, igualmente, machistas e patriarcais. O discurso transverso do "homem macho" remete a interdiscursos como o do homem de sucesso, do homem de dinheiro e, por conseguinte, do homem com mulheres, em que o ataque discursivo à masculinidade materializa uma ofensa de grande tom injurioso.

Destarte, o diálogo entre os dois constitui-se em batalha, em que a arma principal é a linguagem ferina, demarcada no discurso injurioso, por meio de gírias e palavrões, cujo fio do discurso é a ofensa. o duelo entre os dois se constitui ideologicamente e cava na psique de cada um traumas e recalques, desvelados e desnudados via linguagem, no discurso de sujeitos clivados.

O ambiente em que esse conflito ocorre é degradado, descrito nos limites de um quarto de hospedaria e do mercado em que trabalham. A condição de vida é ínfima, dentro dos ditames da formação ideológica capitalista em que dinheiro e sucesso são o fim último. 
A personagem Tonho demonstra em seus enunciados certa fraqueza e ingenuidade, o calão lhe serve de defesa, enquanto para Paco há um tom ofensivo mais aclarado. Toda a construção discursiva vai delineando tal quadro; contudo, no final da trama, ocorre uma inversão do discurso em cena. Às raias do desespero, Tonho mata Paco e assume

Cezar o comportamento, a identidade e o discurso do colega:

Roberto Versa

Alexandre

Sebastião estourando de rir! (Toca a gaita e dança.) Até danço de alegria! Eu sou mau! Eu sou o Tonho Maluco, o Perigoso! Mau Pacas! (p. 134).

Ferrari Soares

Quando Tonho sofria o ataque injurioso no nível discursivo, Paco 300 sempre demarcava ser o "Paco Maluco", o "Perigoso". Agora morto, o discurso não é mais seu, como se algum dia tivesse sido. O sujeito assujeitado mau e maluco, marcado nessa FD, agora é Tonho, que, em desvario, assume o discurso do colega. Eis a cena final e o discurso (em) cena.

\section{Referências}

ALTHUSSER, Louis. Aparelhos ideológicos de Estado. 7. ed. Rio de Janeiro: Graal, 1998.

CACCIAglia, Mário. Pequena história do teatro no Brasil. São Paulo: EDUSP, 1986.

GADET, Françoise et al. Apresentação da conjuntura em linguística, em psicanálise e em informática aplicada ao estudo dos textos na França, em 1969. In: GADET, Françoise; HAK, Tony. Por uma análise automática do discurso: uma introdução à obra de Pêcheux. Trad. de Bethânia S. Mariani et al. 2. ed. Campinas: Ed. da Unicamp, 1993. p. 39-60.

LACAN, Jacques. O Seminário - Livro 11: os quatro conceitos fundamentais da Psicanálise. Rio de Janeiro: J. Zahar, 1996.

MAGALDI, Sábato. Moderna dramaturgia brasileira. São Paulo: Perspectiva, 1998. 
MARCOS, Plínio. Barrela, Dois perdidos numa noite suja, Navalha na carne, Abajur Lilás, Quero, uma reportagem maldita. São Paulo: Global, 2003.

MARTINS, Helena. Três caminhos na filosofia da linguagem. In: MUSSALIM, Fernanda; BENTES, Anna Christina (Org.). Introdução à linguística: domínios e fronteiras. São Paulo: Cortez, 2005. v. 3, p. 353-391.

MORAVIA, Alberto. O terror de Roma. In: Contos romanos. Trad. de Alessandra Caramori. São Paulo: Berlendis \& Vertecchia, 2002. p. 245-261.

Efeitos de sentido em "Dois perdidos numa noite suja"

MUSSALIM, Fernanda. Análise do Discurso. In: ; BENTES, Anna Christina (Org.). Introdução à linguística: domínios e fronteiras. São Paulo: Cortez, 2001. v. 2, p. 101-142.

PÊCHEUX, Michel. Metáfora e interdiscurso. In: ORLANDI, Eni Pulcinelli. Análise do discurso: Michel Pêcheux. 2. ed. Campinas: Ed. da Unicamp, 2011. p. 151-161.

Semântica e discurso: uma crítica à afirmação do óbvio. 3. ed. Campinas: Ed. da Unicamp, 1997.

; FUCHS, Catherine. A propósito da análise automática do discurso: atualização e perspectivas (1975). In: GADET, Françoise; HAK, Tony. Por uma análise automática do discurso: uma introdução à obra de Pêcheux. Trad. de Bethânia S. Mariani et al. 2. ed. Campinas: Ed. da Unicamp, 1993. p. 163-179.

POSSENTI, Sírio. Teoria do discurso: um caso de múltiplas rupturas. In: MUSSALIM, Fernanda; BENTES, Anna Christina (Org.). Introdução à linguística: domínios e fronteiras. São Paulo: Cortez, 2005. v. 3, p. 353-391.

REMENCHE, M. L. R. As criações metafóricas na gíria do Sistema Penitenciário do Paraná. 2003. 107 f. Dissertação (Mestrado em Estudos da Linguagem)-Universidade Estadual de Londrina, Londrina, 2003. 
TEIXEIRA, Marlene. Análise do discurso e psicanálise: elementos para uma abordagem do sentido no discurso. 2. ed. Porto Alegre: EdiPUCRS, 2005.

Cezar

Roberto Versa

Alexandre

Sebastião

Ferrari Soares

302 